\title{
Recent Development on Plant Aldehyde Dehydrogenase Enzymes and Their Functions in Plant Development and Stress Signaling
}

\author{
Adesola J. Tola (D, Amal Jaballi, Hugo Germain (D) and Tagnon D. Missihoun *(D) \\ Groupe de Recherche en Biologie Végétale (GRBV), Department of Chemistry, Biochemistry and Physics, \\ Université du Québec à Trois-Rivières, 3351 boul. des Forges, Trois-Rivières, QC G9A 5H7, Canada; \\ adesola.tola@uqtr.ca (A.J.T.); Amal.Jaballi@uqtr.ca (A.J.); hugo.germain@uqtr.ca (H.G.) \\ * Correspondence: Tagnon.Missihoun@uqtr.ca; Tel.: +1-819-376-5011 (ext. 3365)
}

Citation: Tola, A.J.; Jaballi, A.; Germain, H.; Missihoun, T.D. Recent Development on Plant Aldehyde Dehydrogenase Enzymes and Their Functions in Plant Development and Stress Signaling. Genes 2021, 12, 51. https: / / doi.org/10.3390/ genes12010051

Received: 2 December 2020 Accepted: 28 December 2020 Published: 31 December 2020

Publisher's Note: MDPI stays neutral with regard to jurisdictional clai$\mathrm{ms}$ in published maps and institutional affiliations.

Copyright: $(\odot 2020$ by the authors. Licensee MDPI, Basel, Switzerland. This article is an open access article distributed under the terms and conditions of the Creative Commons Attribution (CC BY) license (https:// creativecommons.org/licenses/by/ $4.0 /)$.

\begin{abstract}
Abiotic and biotic stresses induce the formation of reactive oxygen species (ROS), which subsequently causes the excessive accumulation of aldehydes in cells. Stress-derived aldehydes are commonly designated as reactive electrophile species (RES) as a result of the presence of an electrophilic $\alpha, \beta$-unsaturated carbonyl group. Aldehyde dehydrogenases (ALDHs) are $\mathrm{NAD}(\mathrm{P})^{+}$-dependent enzymes that metabolize a wide range of endogenous and exogenous aliphatic and aromatic aldehyde molecules by oxidizing them to their corresponding carboxylic acids. The ALDH enzymes are found in nearly all organisms, and plants contain fourteen ALDH protein families. In this review, we performed a critical analysis of the research reports over the last decade on plant ALDHs. Newly discovered roles for these enzymes in metabolism, signaling and development have been highlighted and discussed. We concluded with suggestions for future investigations to exploit the potential of these enzymes in biotechnology and to improve our current knowledge about these enzymes in gene signaling and plant development.
\end{abstract}

Keywords: aldehyde dehydrogenases; abiotic stress; gene density; stress signaling; protein carbonylation

\section{Introduction}

Abiotic and biotic stresses increase the levels of the reactive oxygen species (ROS) including hydrogen peroxide, hydroxyl radical and superoxide radical in plants. Developing crops with the enhanced capability to maintain low ROS levels and reduce their damaging effects has remained an important goal in plant physiology, biotechnology and breeding. The superoxide anion radical and hydrogen peroxide can directly oxidize lipids or be converted to a hydroxyl radical in vivo through the Fenton and Haber-Weiss reactions. A hydroxyl radical readily initiates the peroxidation of the poly-unsaturated fatty acids (PUFAs), mainly linoleic and linolenic acids. Spontaneous rearrangements of the oxidized PUFAs lead to the generation of various phytoprostanes and aldehydes such as 4-hydroxy-2-nonenal, hexanal, (E) 2-hexenal and malondialdehyde (MDA) [1,2]. Many of the lipid peroxidation products, including MDA, are commonly designated as reactive electrophile species (RES) as they contain an electrophilic (electron-accepting) $\alpha, \beta$-unsaturated carbonyl group. To cope with the detrimental effects of RES, the cells use diverse enzymatic and non-enzymatic detoxifying systems. Reactive aldehydes are detoxified by either the reduction of their carbonyl group to alcohol or the oxidation to the corresponding carboxylic acid [3]. The oxidative reaction is catalyzed by $\operatorname{NAD}(\mathrm{P})^{+}$-dependent aldehyde dehydrogenases (ALDHs, EC 1.2.1.3) that represent a large protein superfamily, of which, the members are widely distributed from human to plant genomes [4,5]. The ALDH genes are named according to the nomenclature proposed by Vasiliou et al. [4]. The gene names contain the root symbol "ALDH", followed by a number representing the family and a letter representing the subfamily. The last number, after the letter of the subfamily, denotes 
the individual gene within that subfamily. Gene subfamilies and numbers are given chronologically following their identification. ALDH proteins that share at least $40 \%$ and $60 \%$ sequence identity are grouped into the same family and the same subfamily, respectively. Several human ALDH enzymes also catalyze ester hydrolysis [6]. The last twenty years have witnessed important insights in plant ALDH proteins [7-12] but our knowledge about their functions has significantly improved since the last review on the subject [13]. In this review article, we provided a detailed analysis of the research reports over the last decade with an emphasis on the roles of plant ALDHs in metabolism, signaling and development. We also highlighted the areas still obscure that require further research to understand the role of the plant ALDHs in the control of gene expression, metabolism, growth and development.

\section{The ALDH Superfamily}

Plants contain fourteen ALDH protein families-of which, the families ALDH11, ALDH12, ALDH19, ALH21, ALDH22, ALDH23 and ALDH24 are only found in plants, whereas the families ALDH2, ALDH3, ALDH5, ALDH6, ALDH7 and ALDH10 are also present in humans [13]. In comparison to Arabidopsis, which has 16 ALDH genes represented in 10 protein families, almost twice this gene number was found in species such as Malus domestica Borkh. (39 genes), Gossypium raimondii Ulbr. (30 genes), Solanum lycopersicum L. (29 genes), Brassica rapa subsp. pekinensis (Lour.) Hanelt (27 genes) and Cicer arietinum L. (27 genes) [13-18]. The major driver of the ALDH family expansion is not clear so far. In contrast to the number of $A L D H$ genes, the $A L D H$ gene density, which we defined as the ratio of the genome size to the number of $A L D H$-coding genes in the genome, reflects well on how the expansion of the $A L D H$ gene families followed that of the species genome (Table 1). However, no trend could be seen between the developmental complexity of the species (unicellular versus multicellular and vascular versus non-vascular) and the $A L D H$ gene density or the number of $A L D H$ genes in the species. This, apparently, supports the thesis that plants contain a core set of ALDHs to which new ALDH genes are added or lost during genome expansion [14]. However, further studies are required to better understand the distribution of the $A L D H$ genes during evolution. Indeed, no information is currently available on ALDHs in streptophyte algae, which contain the closest algal relatives of land plants and are of great interest to understanding the evolutionary roots of stress responses in terrestrial plants [19]. A lack of knowledge is also noted about the ALDHs in many land plants, including ferns, Marchantia polymorpha L., 1753 and Anthoceros hornworts [20-22]. Moreover, it remains unclear what drove the change of the core set of ALDHs in the unicellular species and the multicellular vascular and non-vascular species. We hypothesize that environmental conditions and metabolic requirements might play a major role.

\subsection{ALDH Catalytic Activities and Importance in Plant Development}

The ALDH enzymes require pyridine cofactors for their catalytic activity. Most plant ALDHs tend to prefer $\mathrm{NAD}^{+}$over NADP ${ }^{+}$, except the ALDH11, ALDH18 and ALDH19 family proteins that were shown to use NADP exclusively [15-17]. By using the Arabidopsis ALDH3H1 as an example, Stiti, et al. [18,43] showed that the residues E149, V178 and I200 are critical for the specificity toward $\mathrm{NAD}^{+}$. The site-directed mutagenesis of these amino acid residues into threonine, arginine and valine, respectively, shifted the cofactor preference to $\mathrm{NADP}^{+}$[18]. Kinetic studies of a few plant and animal ALDHs showed that their catalytic mechanism follows a Bi-ordered steady-state kinetic [44,45]. Most ALDHs have a broad substrate specificity, meaning that they can oxidize a range of aliphatic aldehydes compounds, whereas few showed a narrow specificity. These include members of the subfamily ALDH2C and of the families ALDH5, ALDH6, ALDH10, ALDH11, ALDH12, ALDH18 and ALDH19 $[9,13]$. As a consequence of their broad substrate specificity and presence in nearly all cell compartments, the ALDHs are very redundant in their functions [11]. Stiti et al. [46] investigated the possibility of probing ALDH activity in vivo by 
active site-labeling. The labeling of the Arabidopsis ALDH3H1 with a chloroacetamide probe occurred at the catalytic Cys and correlated with the enzyme activity. However, the probe also targeted other ALDHs than ALDH3H1 and became inhibited by the enzyme co-factor $\mathrm{NAD}^{+}$. These observations illustrated the difficulty to relate the function of an ALDH isoform in the cell to its activity towards a substrate. Despite this apparent limitation, recent studies revealed the substrate specificity of a few enzymes of the subfamily ALDH2C and of the families ALDH3 and ALDH10 and the association with physiological processes.

Table 1. Evolution of the $A L D H$ gene number and $A L D H$ gene density in selected plant species.

\begin{tabular}{|c|c|c|c|c|c|}
\hline Clades & Species & $\begin{array}{c}\text { Genome Size } \\
\text { (Mbp) }\end{array}$ & $\begin{array}{c}\text { ALDH Gene } \\
\text { Number }\end{array}$ & $\begin{array}{c}\text { a } A L D H \text { Gene Density } \\
\text { (Mbp/ALDH) }\end{array}$ & b References \\
\hline \multirow{3}{*}{ Microalgae } & Ostreococcus tauri & 13 & 6 & 2.17 & [23] \\
\hline & Volvox cateri & 138 & 7 & 19.71 & [24] \\
\hline & Chlamydomonas reinhardtii & 118 & 9 & 13.11 & [25] \\
\hline \multirow[b]{2}{*}{ Mosses } & Syntrichia caninervis & 45 & 15 & 3.03 & [26] \\
\hline & Physcomitrella patens & 472 & 21 & 22.47 & {$[27]$} \\
\hline \multirow{14}{*}{ Vascular plants } & Arabidopsis thaliana & 136 & 16 & 8.47 & [28] \\
\hline & Eutrema salsugineum & 243 & 17 & 14.30 & [29] \\
\hline & Sorghum bicolor & 730 & 19 & 38.42 & [30] \\
\hline & Oryza sativa & 372 & 20 & 18.60 & {$[31,32]$} \\
\hline & Setaria italica & 423 & 20 & 21.15 & [33] \\
\hline & Zea mays & 2106 & 22 & 95.73 & [34] \\
\hline & Selaginella moellendorffii & 213 & 24 & 8.86 & [35] \\
\hline & Vitis vinifera & 486 & 25 & 19.45 & [36] \\
\hline & Populus trichocarpa & 423 & 26 & 16.27 & [37] \\
\hline & Brassica rapa & 353 & 27 & 13.08 & [38] \\
\hline & Solanum lycopersicum & 900 & 29 & 31.03 & [39] \\
\hline & Gossypium raimondii & 748 & 30 & 24.93 & [40] \\
\hline & Malus domestica & 650 & 39 & 16.66 & [41] \\
\hline & Glycine max & 1013 & 53 & 19.12 & [42] \\
\hline
\end{tabular}

a The $A L D H$ gene density represents the ratio of the genome size to the number of aldehyde dehy-drogenase (ALDH)-coding genes in the genome. ${ }^{b}$ The genome size information was retrieved from the database Ensembl for plants, https://plants.ensembl.org/, if not otherwise stated.

\subsubsection{ALDH2}

The ALDH2 enzymes are mitochondrial proteins, except for the subfamily $2 \mathrm{C}$ enzymes that are cytosolic $[47,48]$. Like most ALDH enzymes, the ALDH2 enzymes can oxidize a large number of aliphatic aldehyde substrates, but the subfamily $2 C$ prefers aromatic substrates. The ALDH2C4 protein from A. thaliana was shown to oxidize sinapaldehyde and coniferaldehyde into sinapic acid and ferulic acid, respectively [47]. The findings indicated that these ALDHs are also involved in terpenoid metabolism in citrus [49]. Numerous compounds are derived from benzoic acid in plants, which include cytokinins, salicylic acid, glucosinolates and benzenoids, which constitute the aroma of many fruits and natural volatile compounds [50-53]. An ALDH2 enzyme in Antirrhinum majus L. (snapdragon) was shown to oxidize benzaldehyde into benzoic acid via the non- $\beta$-oxidative route in vivo [54]. Besides aliphatic and arylic aldehydes, pyrazole and imidazole containing aldehydes were shown to be oxidized by maize ALDH2C-type enzymes. The maize recombinant $\mathrm{ALDH} 2 \mathrm{C} 1$ enzyme (RF2C) readily oxidized 1-pyrimidinyl-4-imidazole carbaldehyde, 3-pyrazole carbaldehyde, 5-pyrazole carbaldehyde and 1-benzyl-4-pyrazole carbaldehyde, while the recombinant ALDH2C4 enzyme efficiently oxidized 2-phenyl4-imidazole carbaldehyde [55]. These azole-containing aldehyde compounds are often intermediates of alkaloids and synthetic drugs, suggesting that ALDH2C proteins may be involved in the biosynthesis of azole-containing pesticides or repellents produced by plants. These findings indicate that plant ALDH2C enzymes may serve to engineer the biosynthesis of floral scents and many plant natural compounds via the non- $\beta$-oxidative 
pathway of benzoic acid biosynthesis. The plant ALDH2C enzymes could also be used in synthetic biology for the production of imidazole and pyrazole-derivatives used as antibiotics or antifungal drugs. In this regard, the comparison of the ALDH2C amino acid sequence revealed that few amino acid residues are conserved in dicotyledons but substituted by non-equivalent residues in monocotyledons [56]. For instance, ALDH2C1 contains a phenylalanine at position 466, which is conserved in the ALDH2C isoforms in the monocots Brachypodium distachyon (L.) P.Beauv., Oryza sativa L., Sorghum bicolor (L.) Moench, and Setaria italica (L.) P.Beauv. However, the homologs of the ALDH2C gene in the dicots A. thaliana, G. raimondii, Populus trichocarpa Torr. \& A.Gray, Glycine max (L.) Merr. and Eutrema salsugineum (Pall.) contain a tyrosine in the equivalent position. Protein structure modeling suggested that the presence of tyrosine would widen the substrate-binding pocket in the dicotyledons and thereby influence substrate specificity [56]. These findings remain to be verified experimentally, but they suggest that specific amino acid substitutions between the ALDH2C isoforms in dicotyledon and monocotyledon species could further fine-tune the enzyme activity toward secondary metabolite substrates.

Few studies have underlined the importance of the ALDH2 enzyme activity in plant development. Cui et al. [7] isolated the first ALDH gene from maize that encodes a mitochondrial class-2 ALDH ( $R f 2 a$ or ALDH2B2). ALDH2B2 (Rf2a) was identified as the nuclear restorer of cytoplasmic male sterility in maize and shown to be involved in anthers development [7,48,57], but the mechanisms of action were unclear. Very recently, Xie et al. [58] showed that OsALDH2b, an orthologous gene of $A L D H 2 B 2$ in rice (O. sativa), negatively regulates tapetal-programmed cell death. OsALDH $2 b$ was highly expressed in anthers from meiosis to the early microspore stage. Plants deficient in $O s A L D H 2 b$ accumulated excess malondialdehyde and showed early programmed cell death in the tapetum, causing premature tapetum degeneration and abnormal microspore development [58]. These results provided further insight into the role of ALDH2B proteins in anthers development.

\subsubsection{ALDH3}

Zeaxanthin is the common precursor for three major classes of apocarotenoids: crocins, picrocrocin and safranal. The cleavage of zeaxanthin by carotenoid cleavage dioxygenase 2 (CCD2) leads to 3-OH- $\beta$-cyclocitral and crocetin dialdehyde. Studies in saffron, a spice produced from the stigmas and styles of Crocus sativus L., suggested that ALDH3I1 is involved in the oxidation of crocetin dialdehyde to crocetin [59,60]. CsALDH3I1 was shown to have a strong preference to $\beta$-apo- $8^{\prime}$-carotenal. This activity is reminiscent to that of ALDH3H1, which oxidizes ether-alkane aldehyde in the jojoba plant (Simmondsia chinensis (Link) C.K.Schneid.) [61]. So far, only the ALDH2C and ALDH3 enzymes were shown to efficiently oxidize aromatic and long-chain aldehydes. They could be useful in synthetic biology, as shown recently by Liu et al. [62].

\subsubsection{ALDH5, ALDH6 and ALDH7}

The plant ALDH5 genes encode a succinic semialdehyde dehydrogenase involved in the operation of the GABA shunt pathway (see, also, ALDH21 below) [63,64]. The ALDH6 protein family is represented by a single gene, AT2G14170, encoding a methylmalonatesemialdehyde dehydrogenase in $A$. thaliana and in rice $[9,11,13]$. The enzyme is proposed to be involved in the oxidative decarboxylation of methylmalonate semialdehyde into propionyl-CoA during the catabolism of branched-chain amino acids [65]. The gene could be involved in the recycling of carbon skeletons from amino acid degradation during senescence or stress. The findings also suggested that the enzyme might play a role in root development and leaf sheath elongation in rice [66]. Mutant analyses are required to elucidate the physiological role of ALDH6B2 in plants. The plant ALDH7 enzymes oxidize a broad range of aldehyde substrates [67]. ALDH7 proteins appear to be expressed in all plant tissues and to be the most stress-inducible ALDH proteins $[10,68,69]$. The ALDH7B4 in A. thaliana was also induced upon herbicide treatment [70]. The mutation of the ALDH7 gene in rice led to impaired seed development due to increasing Amadori products and 
reactive aldehydes [12]. Li et al. reported that a transgenic soybean line overexpressing an aldehyde dehydrogenase gene developed larger seeds than the wild-type genotype, but the identity of that gene was not properly indicated [71]. These findings collectively indicate the implication of the $A L D H$ genes in seed development, size and viability.

\subsubsection{ALDH10}

The plant ALDH10 enzymes are aminoaldehyde dehydrogenases (AMADHs, EC 1.2.1.19) involved in the oxidation of several nitrogen-containing aldehydes, including betaine aldehyde. They are associated with polyamine catabolism and the biosynthesis of compatible solutes, fragrance and carnitine [11,72-75]. AMADH1 in tomatoes (S. lycopersicum) was also used to detect furfural and its derivatives as side-products of the thermal degradation of sugars in plum brandy [76]. These findings underline the potential of these enzymes in plant biotechnology. Biochemical analyses showed that the high catalytic efficiency of AMADHs towards $\omega$-aminoaldehydes is defined by the presence of aspartic acid and aromatic residues in the substrate channel $[77,78]$. Studies in peas (Pisum sativum L.) found that substrates with diverse branching and acyl chain lengths derived from the natural aminoaldehyde substrate had less influence on the enzyme activity than the size of the natural non-branched aminoaldehyde substrates [79]. Moreover, the oxidation of betaine aldehyde by the ALDH10 enzymes generate glycine betaine (GB), which accumulates in the plant cells as an osmolyte under osmotic stress. However, not all plants accumulate GB, although most plants express two functional ALDH10 genes [73,80-82]. For example, spinach (Spinacia oleracea L.) is a GB accumulator, whereas A. thaliana is not. The analysis of the crystal structure of spinach betaine aldehyde dehydrogenase (SoBADH) uncovered what confers BADH activity to the ALDH10 enzymes. Diaz-Sanchez et al. [83] showed that tyrosine Y160 and tryptophan W456 (spinach enzyme numbering) are strictly conserved in plant ALDH10s and form a pocket that accommodates the bulky trimethylammonium group. This pocket is reduced in ALDH10s with low BADH activity, because an isoleucine pushes tryptophan against tyrosine. In comparison, ALDH10s with high BADH activity have alanine (A441 in SoBADH) or cysteine instead of isoleucine, which leaves enough room for the binding of BAL. Accordingly, the mutation A441I decreased the catalytic efficiency of SoBADH about 200 times, while the mutation A441C had no effect [83]. Phylogenetic analyses suggested that the BADHs with high catalytic efficiency evolved from ancestral AMADHs through the mutations I441A or I441C (SoBADH numbering) [84]. The overexpression of ALDH10 isoforms with high BADH activity was investigated in several studies and showed to confer stress tolerance to the plants. Recently, the two ALDH10 proteins in A. thaliana, AtALDH10A8 and AtALDH10A9, were shown to oxidize trimethylaminobutyraldehyde into $\gamma$-butyrobetaine, the precursor of carnitine [85]. The double mutants contained low $\gamma$-butyrobetaine level, but no difference was found in the carnitine contents of the wild type and the mutants. While the single mutant had no phenotype under normal growth conditions, a high number of seeds failed to mature in the siliques of the double mutants, and the seeds that matured germinated faster than the wild type. The Arabidopsis ALDH10 enzymes thus appeared to be involved in seed development via the synthesis of $\gamma$-butyrobetaine. The precise function of $\gamma$-butyrobetaine in seed development remains to be elucidated.

\subsubsection{ALDH11}

ALDH11 encodes non-phosphorylating glyceraldehyde-3-phosphate dehydrogenase (GAPN; E.C. 1.2.1.9), which oxidizes glyceraldehyde-3-phosphate to 3-phosphoglycerate in a $\mathrm{NADP}^{+}$-dependent manner in the cytosol [86]. The enzyme acts as a vehicle for NADPH export from the chloroplast to the cytosol. There is one ALDH11 gene in A. thaliana, and a loss-of-function mutation in ALDH11 altered the expression of enzymes of the carbohydrate metabolism and caused the repression of photosynthetic genes [87]. This underlines the importance of ALDH11 enzymes in the plant metabolism. The reaction catalyzed by ALDH11 parallels the oxidative phosphorylation of glyceraldehyde-3-phosphate to 1,3- 
bisphosphoglycerate by phosphorylating glyceraldehyde-3-phosphate dehydrogenases (GAPDHs, E.C. 1.2.1.12). By competing for the same substrates with GAPDHs, the ALDH11 enzyme likely acts as a node of regulation for plant glycolysis.

\subsubsection{ALDH12, ALDH18 and ALDH19}

Proline was also shown to function in seed germination, root elongation, flowering, embryo development and pollen fertility [88-94]. The ALDH12 proteins encode a $\mathrm{NAD}^{+}$-dependent glutamate $\gamma$-semialdehyde dehydrogenase (GSALDH) that oxidizes glutamate $\gamma$-semialdehyde (GSAL), a mitochondrial intermediate of the proline and arginine catabolism, to glutamate. As proline catabolism enzymes, they were shown to be downregulated under high salt or dehydration stresses in maize and the moss P. patens to allow the accumulation of proline as a compatible solute [95]. They are involved in proline homeostasis. In contrast to ALDH12, the ALDH19 family codes for the $\gamma$-glutamyl phosphate reductase involved in proline biosynthesis. The only member known for this family was found in tomatoes $[96,97]$. The $\gamma$-glutamyl phosphate reductase enzyme was found as a bifunctional protein showing also $\gamma$-glutamyl kinase (GK) activity [96]. Using the entire sequence of this bifunctional enzyme in the blast searches may not give significant hits because of the coding region for $\gamma$-glutamyl kinase activity. However, using solely the sequence of the $\gamma$-glutamyl phosphate reductase may help find other potential ALDH19 proteins in other species. Similarly, the plant $\{$ Delta $\}$ 1-Pyrroline-5-Carboxylate Synthetase (P5CS), encoded by a gene of the ALDH18 protein family, is involved in the biosynthesis of proline. The P5CS protein is a bifunctional enzyme that has amino-acid kinase and aldehyde dehydrogenase activities. Proline is an osmoprotectant that accumulates in plants under stress conditions. The ability of the plants to accumulate important levels of proline to fight against stress caused by low water potential appeared to evolve with time [98]. Genetic variations in proline accumulation and the associated stress tolerance were found between accessions of $A$. thaliana [99]. Downregulation of the ALDH18 genes impaired the seed germination in $A$. thaliana, reduced the size of the root meristem and delayed bolting [93,100,101]. In contrast, the ectopic expression of ALDH18 in switchgrass (Panicum virgatum L., 1753) resulted in faster growth and earlier flower development than in wildtype plants [102]. Similarly, transgenic plants of A. thaliana overexpressing ALDH18 had a shorter vegetative growth in short-day conditions [103]. As the key proline biosynthetic genes, ALDH18 genes appears to influence plant stress responses, vegetative growth and flowering. It remains unclear whether they are targeted by the same or different regulators in these physiological processes. The elucidation of this question may shed light on the question of whether normal flowering and stress-induced flowering are controlled by common mechanisms.

\subsubsection{ALDH21, ALDH22, ALDH23 and ALDH24}

ALDH21 family proteins are absent in the flowering plants but are found in lower plants, including green algae, bryophytes, lycophytes and ferns. Bryophytes are nonvascular plants encompassing mosses, hornworts and liverworts. The ALDH21 protein family is represented by a single gene in P. patens, S. moellindorffii, Syntrichia ruralis Hedw. and S. caninervis $[13,14,104-106]$. The biochemical characterization of ALDH21 from $P$. patens revealed that it encodes a tetrameric $\mathrm{NADP}^{+}$-dependent succinic semialdehyde dehydrogenase (SSALDH) that converts succinic semialdehyde, an intermediate of the $\gamma$-aminobutyric acid (GABA) shunt pathway, into succinate in the cytosol [106]. The presence of a succinic semialdehyde dehydrogenase suggests the operation of the GABA shunt pathway in non-flowering species. The equivalent enzyme in the flowering plant $A$. thaliana is a mitochondrial protein of the ALDH5 family that uses $\mathrm{NAD}^{+}$as a cofactor. Interestingly, both ALDH5 and ALDH21 are present in some lower plants, indicating that the ALDH21 genes have been lost during the evolution of lower plant species to flowering species. This might bear some advantage for the control of the GABA shunt pathway in flowering species, since any disturbance of this pathway was shown to severely impair the growth 
and flower development in A. thaliana $[63,107]$. Functional studies showed that the ALDH21 gene is induced by water deprivation in the mosses $S$. ruralis and S. caninervis $[104,105]$ and its ectopic expression in tobacco and cotton led to drought and salt-tolerant plants [108,109]. As for ALDH22, ALDH23 and ALDH24, there has been no new reports on their activity and roles since the review work done by Brocker et al. [13]. Therefore, the readers are invited to consult this publication that summarized well the so-far available literature on these plant ALDH protein families.

\subsection{ALDH Gene Regulation}

Gene expressions can be regulated at the transcriptional and posttranscriptional levels in eukaryotes. Previous findings showed that stress-inducible ALDHs are regulated at the transcriptional level by ABA [11,110]. Comparisons of the ALDH7 gene promoter sequences of different Brassicaceae identified a conserved ACGT-containing motif and a dehydration-responsive element/C-repeat low temperature-responsive element, which control $A L D H 7 B 4$ expression in seeds and induction by salt, dehydration and ABA in leaves [68]. NAC (no apical meristem, NAM, ATAF1/2 and CUC2) transcription factors control diverse biological processes in response to stress, developmental and hormonal signals [111,112]. Several NAC transcription factors, including ATAF1, were found to bind and activate the $A L D H 7 B 4$ promoter [113]. ATAF1 directly binds to and activates the promoter. The overexpression of ATAF1 (At1g01720) in Arabidopsis plants results in the elevated expression of $A L D H 7 B 4$ in seeds, seedlings and mature plants, whereas ATAF1 knock-out mutant plants display abolished expressions of $A L D H 7 B 4$. These findings indicate that $A L D H 7 B 4$ and likely other stress-responsive ALDHs that also contain ACGT and DRE/CRT motifs are common targets of NAC transcription factors. As in animals, alternative gene splicing has been reported for a few plant $A L D H$ genes. These include $A L D H 3 H 1$ in $A$. thaliana and $A L D H 2 B 4$ in grapevines [114,115]. For $A L D H 3 H 1$, one variant lacks the first exon of the main transcript but contains a cryptic exon that is absent in the main gene transcript. The other AtALDH3H1 splice variants contain premature stop codon leading to truncated proteins, but gene expression analyses revealed that some of these variants were induced upon water stress. Moreover, it was found that the gene contains a long first intron that harbors cis-elements that restrict the expression of the splicing variants to the base of fresh leaves near the shoot meristem location [114]. Likewise, in grapes, three splicing variants were identified: $V v A L D H 2 B 4 \_v 1, V v A L D H 2 B 4 \_v 2$ and VvALDH2B4_v3. VvALDH2B4_v1 and $V v A L D H 2 B 4 \_v 3$ bear different $3^{\prime}$ splicing acceptor sites in the third exon, while $V v A L D H 2 B \_v 2$ has an intron retention that leads to a different translation initiation site. The functions of these transcript variants in the two species remain unclear. The transcription of certain plant $A L D H$ genes may also be controlled via intragenic methylation [116]. The methylation-sensitive amplification polymorphism (MSAP) assay revealed that $A L D H 2 B 7 a$ in potatoes (S. tuberosum) is differentially methylated at cytosine sites within an intron and an exon in response to lower temperature treatments. Although several plant ALDHs are considered to be involved in the detoxification of stress-derived aldehydes, these findings suggest that some ALDHs with potent roles in primary and secondary metabolisms might be temporally repressed by this mechanism in other to avoid a waste of resources under stress conditions. In addition to the regulation at the transcriptional level, ALDHs can also be targeted by post-translational modifications. Cysteine in the catalytic site of ALDH3I1 and ALDH3H1 can undergo reversible S-nitrosylation in vitro, indicating a possible inactivation of these enzymes in vivo by nitrosylation [117]. Likewise, profiling of the carbonylated proteome in A. thaliana identified carbonylated ALDH7B4-derived peptides [118].

\section{ALDH Roles in Abiotic Stress Responses}

The enzymatic scavenging of aldehydes derived from stress-related lipid peroxidation involves ALDHs. The suppression of the ALDH2C4 gene in Nicotiana benthamiana Domin led to plants that were more sensitive to lower-temperature stresses and accumulated 
more ROS and malondialdehyde [116]. The ALDH2B7a enzyme enhanced the cold stress tolerance in potatoes (S. tuberosum) [116]. The ectopic expression of the AtALDH2B7 gene in $A$. thaliana under control of the drought-inducible promoter of the tryptophan-rich sensory protein (TSPO) gene also conferred drought stress tolerance to the transgenic plants [119]. Transgenic tobacco (Nicotiana tabacum L.) and Arabidopsis plants constitutively expressing the soybean $A L D H 7$ gene (GmTP55) were tolerant to high salinity during germination and to water deficit during plant growth [120]. These transgenic plants also exhibited an enhanced tolerance to oxidative stress by maintaining a low level of lipid peroxidationderived aldehydes. Likewise, transgenic tobacco plants overexpressing the ALDH22A1 gene from maize (Zea mays L.) showed increased stress tolerance accompanied by a reduction of MDA derived from the lipid peroxidation [121]. Three homologs of the ALDH7B4 gene were found to be induced by osmotic stress in wheat [122]. The heterologous overexpression of the TraeALDH7B1-5A gene (present in chromosome 5A) in A. thaliana led to enhanced drought tolerance in transgenic plants [122]. Similarly, the overexpression of the Brassica rapa L., 1753 BrALDH7B2 protein in tobacco conferred a tolerance to salt and drought to seedlings [123]. The putative homologous gene of the ALDH7 gene in the streptophyte alga Mougeotia was upregulated upon heat [124]. In Arabidopsis, ALDH3I1 and $A L D H 7 B 4$ are strongly induced by dehydration, high salinity and heat stress, and the double mutant aldh3i1 aldh 764 was more sensitive to heat stress and stress combinations than wild-type plants $[69,110]$. Transgenic plants overexpressing both ALDH proteins were more tolerant to drought and salt stress than the wild type [10,125]. Unlike the wild-type plants, these transgenic plants could survive on media supplemented with 20-mM hydrogen peroxide. Collectively, these findings indicate that plant $A L D H 7$ and $A L D H 3 I$ genes play an important role in stress tolerance in both dicotyledon and monocotyledon species. In comparison to $A L D H 3 I 1$, the $A L D H 3 H 1$ gene was found to be upregulated by salt in seedling roots prominently [11], but the ALDH3H1 overexpressors did not perform better than wild-type plants under drought or high salinity conditions. Sub-cellular localization experiments revealed that ALDH3H1 is targeted to the cytosol, whereas ALDH3I1 contains a plastid transit signal that directs it to the chloroplasts. This implies that these proteins, although from the same family, could be functionally different. It is plausible that the ALDH3H1 protein, instead of having a primordial role in stress tolerance acquisition, could be involved in plant metabolism (see the section on catalytic activities) or maintenance of the root architecture and the integrity of root tissues under stress conditions. During the oxidation reaction catalyzed by the ALDHs, the protons derived from the aldehyde substrates are transferred to the cofactor $\mathrm{NAD}(\mathrm{P})^{+}$to produce $\mathrm{NAD}(\mathrm{P}) \mathrm{H}$. Reduced pyridine nucleotides are important cofactors for the ROS-detoxifying enzymes and for the turnover of oxidized glutathione and ascorbate [126]. The NAD $(\mathrm{P}) \mathrm{H} / \mathrm{NAD}(\mathrm{P})$ ratio in the chloroplasts or the mitochondria was shown to influence ROS homeostasis [127-130]. It was recently found that the mutation of the two prominent stress-inducible $A L D H$ genes in $A$. thaliana, $A L D H 3 I 1$ and $A L D H 7 B 4$, caused a decrease of the $\mathrm{NAD}(\mathrm{P}) \mathrm{H}$ and glutathione pools and lowered the $\mathrm{NAD}(\mathrm{P}) \mathrm{H} / \mathrm{NAD}(\mathrm{P})$ ratio [131]. The double mutant aldh3i1 aldh7b4 was also impaired in the xanthophyll cycle involved in the nonphotochemical quenching (NPQ) mechanism of the photosystem II. These observations indicated a shortage for reduced pyridine nucleotides and, together with the high levels of lipid peroxidation-derived aldehydes, pointed to a role of ALDHs as major contributors to the homeostasis of pyridine nucleotides in plants [131,132]. NAD $(\mathrm{P}) \mathrm{H}$ generated by the activity of stress-induced ALDHs may be used for maintaining glutathione homeostasis and to support the functioning of ROS-detoxifying enzymes, such as the 2-alkenal reductases (AERs) and aldo-keto reductases (AKRs). Indeed, AERs and AKRs require NADPH to reduce the $\alpha, \beta$-unsaturated bond and the carbonyl group of lipid-peroxidation-derived aldehydes to n-alkanal and alcohols, respectively [133-135]. In plant cells, the enzymes NADP-dependent isocitrate dehydrogenase (NADP-ICDH), glucose 6-phosphate dehydrogenase (G6PDH) and non-phosphorylating glyceraldehyde-3-phosphate dehydrogenase (GAPN) and NADP-malic enzyme2 (NADP-ME2) contribute to the NAD(P)H content. 
It will be interesting to examine the relative importance and the functional overlap between these enzymes and the ALDHs in the production of $\mathrm{NAD}(\mathrm{P}) \mathrm{H}$ for ROS detoxification under stress conditions.

\section{ALDH Roles in Biotic Stress Responses}

Records of the direct implication of ALDHs in the plant responses to pathogens are limited, but a few recent studies pointed out the contribution of plant ALDHs to the plant defense response against pests and pathogens. A proteomic approach was used to investigate the molecular pathways involved in the response of oak (Quercus robur L.) to three gall-inducing cynipid wasps (Cynips quercusfolii, Cynips longiventris and Neuroterus quercusbaccarum) [136]. A high level of ALDH2 proteins were associated with the interaction of the wasp C. longiventris with the host plant. The etiology of the increase in ALDH2 in the compatible interaction was unclear but could be to facilitate the nutrition of wasp larvae in the gall. Saini et al. [137] showed that yeast extract induced the accumulation of benzoic acid-derived phytoalexins aucuparin and noraucuparin in Asian pears (Pyrus pyrifolia (Burm.f.) Nakai, 1926). A benzaldehyde dehydrogenase and biphenyl synthase activity were concomitantly induced in the cells of P. pyrifolia treated by yeast extract, indicating an implication of benzaldehyde dehydrogenase in the biosynthesis of biphenyl phytoalexins. The gene responsible for the enzyme activity was not characterized, but a benzaldehyde dehydrogenase found in the petals of snapdragons (A. majus) was shown to derive from a protein with more than $80 \%$ sequence similarity with the plant ALDH2 family proteins [54]. It is, therefore, possible that plant ALDH2 enzymes are involved in the biosynthesis of benzoic acid-derived phytoalexins in response to elicitors and pathogen attacks. The ALDH gene expression was assessed during the interaction of Plasmopara viticola with grapevines [115]. VvALDH11B1 was upregulated in both resistant and partially resistant lines but not in the susceptible line. In parallel, $V v A L D H 2 B 4, V v A L D H 2 B 9, V v A L D H 7 B 5$ and $V v A L D H 10 A 9$ were downregulated in the resistant lines, but no change was seen in the expression of these genes in the susceptible lines. The screening of transcriptomics datasets also revealed that several $A L D H s$ genes were differentially expressed in grapevines after infection with the obligate biotrophic fungus Uncinula necator (Schw.) Burr. that causes powdery mildew, the leaf roll-associated closeter-ovirus-3 (GLRaV-3) and, during infection, by the Bois Noir phytoplasma [115]. Likewise, an ALDH gene, CaALDH1, in peppers (Capsicum annuum L., 1753) was strongly induced by avirulent Xanthomonas campestris pv. vesicatoria (Xcv) Ds1 (avrBsT) infection. The transient co-expression of CaALDH1 with avrBsT significantly enhanced avrBsT-triggered cell death in $N$. benthamiana leaves. Bimolecular fluorescence complementation and coimmunoprecipitation assays showed that CaALDH1 interacts with Xanthomonas type III effector AvrBsT to promote cell death in N. benthamiana. Ectopic overexpression of the CaALDH1 gene in A. thaliana enhanced the defense response to Pseudomonas syringae pv. tomato and Hyaloperonospora arabidopsidis infections [138].

The focus of this review is primarily on the plant ALDH proteins. However, it is worth noticing the recent observations that downregulating the expression of some $A L D H$ genes in plant pathogens negatively impacted their virulence. For example, the silencing of two putative family-four aldehyde dehydrogenase genes potassium-activated aldehyde dehydrogenase $(\mathrm{MoKDCDH})$ and delta-1-pyrrorine-5-carboxylate dehydrogenase $(\mathrm{MoP} 5 \mathrm{CDH})$ in the rice blast pathogen Magnaporthe oryzae significantly compromised the pathogenesis of the fungus [139]. The silencing of $M o K D C D H$ appeared sublethal in the mutants, thereby offering the possibility to target this enzyme for selective inhibition, since most plants do not express ALDH4 family proteins. Similarly, Norvienyeku, et al. [140] showed that methylmalonate-semialdehyde dehydrogenase of the rice blast pathogen Magnaporthe oryzae promotes the pathogenesis of the fungus by regulating the mobilization of Spitzenkörper during germ tube morphogenesis and the formation of appressoria by regulating small branch-chain amino acids, inositol, pyridoxine and AMP/cAMP homeostasis. These suggest that plant pathogens use their own ALDH to overcome the downregula- 
tion of the host plant ALDH enzymes as a virulence mechanism. Likewise, Pseudomonas syringae strain PtoDC3000 employs an indole-3-acetaldehyde dehydrogenase (AldA) to produce auxin indole-3-acetic acid to escape the host defense [141]. The AldC gene, homologous to AldA, was shown to function as a long-chain aliphatic aldehyde dehydrogenase, which likely contributed to the feeding of the pathogen on the aliphatic compounds in the plant apoplast [142-144]. Comparative and evolutionary studies of ALDH between plant and fungal or bacterial plant pathogens may help identify lineage-specific inhibitors to target the plant pathogen enzyme and control plant disease.

Altogether, much less is known about the role of $A L D H$ genes in plant-microbe interactions when compared to the literature on the contribution of ALDHs to plant responses to abiotic stresses. While the ALDH2C proteins are likely involved in the biosynthesis of benzoic acid and benzoic acid-derived phytoalexins, the real effects of the differential expressions of other ALDH proteins remain to be investigated. ROS production is a well-known defense strategy deployed by plants to counter-attack pathogen infections. For instance, the hypersensitive response characterized by localized cell death is orchestrated by ROS produced by the plant during a compatible interaction. Recently, a new form of cell death, called ferroptosis, has been evidenced in plants. Ferroptosis depends on ROS-derived reactive lipid peroxides, but, currently, it is unclear how plants regulate ferroptosis [145-148]. We speculate that this may require the localized expression of ALDHs with a broad substrate specificity to circumvent cell death at the site of infection.

\section{Recent Findings and Perspectives on the Role of Plant ALDHs in Gene Signalling}

Besides their roles in the metabolism and the response to biotic and abiotic stresses, recent studies pointed to the role of ALDH2 genes in the regulation of plant developments and responses to stress. ALDH2B7 was shown as an enzyme of the pyruvate dehydrogenase bypass [149]. In this bypass, pyruvate decarboxylase enzymes convert pyruvate to acetaldehyde, which is then oxidized to acetate. Acetate may subsequently enter the tricarboxylic acid cycle or be used by acetylating enzymes. Interestingly, Arabidopsis histone deacetylase 6 (HDA6) was shown to repress the expression of pyruvate decarboxylase, and $A L D H 2 B 7$ genes and HDA6 mutants are tolerant to drought [150]. It appears that acetate produced by ALDH2B7 via the pyruvate dehydrogenase bypass serves for the acetylation of histones by histone acetyltransferase enzymes and promotes gene expression under stress conditions [150]. In mammalian cells, functional pyruvate decarboxylase can translocate, upon growth hormone or mitochondrial stress-derived signals, from the mitochondria to the nucleus during cell cycle progression to generate a nuclear pool of acetyl-CoA from pyruvate and increase the acetylation of core histones important for $\mathrm{S}$ phase entry [151]. Although the plant PDC1 was shown to localize in the cytosol [119], a possible translocation from the cytosol into the nucleus has not been accessed yet. The acetate derived from the ALDH enzymes in the cytosol may well translocate to the nucleus and serve for histone acetylation [152]. FLOWERING LOCUS C (FLC) is a master repressor of the flowering time. FLC represses SUPRESSOR OF OVEREXPRESSION OF CONSTANS1 (SOC1) and FLOWERING LOCUS T (FT), which induce the expression of genes required for the transition to flowering [153]. FLC expression is modulated by H3K9Ac and H3K14Ac and inhibited through H3K27me3 modification in response to cold stress [154,155]. Recently, Xu et al. [156] found that ALDH3F1 is involved in H3K9 acetylation on the FLC locus via acetate production. The mutation of ALDH3F1 triggered early flowering, whereas the overexpression of ALDH3F1 caused late flowering. Considering the broad substrate specificity of ALDHs, these findings suggest that certain ALDH3F1 and ALDH2B enzymes could provide acetate to histone-acetylating enzymes, thereby connecting plant metabolisms and stress responses to the regulation of gene expressions for growth and development. More research is needed to clarify this hypothesis further. An investigation of the $A$. thaliana transgenic lines expressing the $A L D H 7 B 4$ gene promoter fused to the $\beta$-glucuronidase reporter gene showed that both pentanal and trans-2-hexenal induced the $A L D H 7 B 4$ gene expression. This suggested that proteins involved in the control of 
ALDH expression could be targeted to carbonylation by aldehydes $[157,158]$. A thaliana contains three atypical extra-large G proteins (XLG1-3), in addition to the three canonical alpha, beta and gamma subunits of the G protein-coupled receptors (GPCR) $[159,160]$. The ALDH3H1 protein was shown to interact with the XLG protein in a yeast two-hybrid screening [161]. The interaction of ALDH3H1 with XLG may serve to retain XLG in the cytosol or protect it from covalent modification by the reactive aldehydes [157]. Protein carbonylation often leads to the degradation of targeted proteins and, therefore, may interfere with the cellular signaling pathways [162]. In agreement with this, ROS-mediated protein carbonylation has recently been demonstrated to mediate gene expression and signaling by ABA and auxins [163-165]. Future research should focus on identifying the signal transduction proteins targeted by carbonylation via the aldehydes and reactive electrophile species. Since auxins and ABA regulate several developmental processes in plants, the roles of ALDHs in fine-tuning the action of these phytohormones will also be useful.

\section{Conclusions and Perspectives}

The data presented here contributed to the understanding of the function and regulation of aldehyde dehydrogenases in plants over the last decade. Novel functions were identified for the ALDHs of the subfamilies $2 \mathrm{~B}$ and $2 \mathrm{C}$ and families 3,7 and 10. The ALDH2B proteins are involved in histone acetylation by generating acetate from acetaldehyde. They could, thereby, influence several developmental processes, including the development of floral organs. In addition to the previously known role of ALDH2C in the biosynthesis of sinapic acid and ferulic acid in A. thaliana, it appears that these proteins play a role in the plant response to pathogens through the biosynthesis of benzaldehyde-derived phytoalexins. Plant ALDH2C enzymes may be used to engineer floral scents and many plant natural compounds via the non- $\beta$-oxidative pathway of benzoic acid biosynthesis. The plant ALDH2C enzymes could also be used in synthetic biology for the production of imidazole and pyrazole derivatives used as antibiotics or antifungal drugs. Moreover, it would be interesting to investigate their role in the development and integrity of the plant cell wall. In the ALDH3 family, further studies are needed to understand the precise functions of the members. We suspect that gene neofunctionalization might diversify their function and the range of their preferred substrates in various species. A feature of the $A L D H 3 H 1$ gene uncovered in A. thaliana is the existence of an alternative promoter within the upstream intron that directs the expression of an alternative first exon transcript and several splicing variants. Further experiments are required to deepen the functional relevance of the ALDH3H1 transcript variants. Findings have shown that ALDH3I1 and ALDH7B4 proteins are strongly responsive to stress and contribute to the availability of reducing equivalents for ROS detoxification $[10,125,131]$. Further studies are needed to examine the overlap between these ALDHs and other enzymes known to generate $\mathrm{NAD}(\mathrm{P}) \mathrm{H}$ for ROS detoxification or metabolism. New examples of the implication of the ALDH10 enzymes in the development of plant aromas were described in this review. This data underlines the potential of using these enzymes as a target to engineer aromas in plants. Lastly, the ALDHs, by oxidizing reactive carbonyl species, counteract protein carbonylation. Like protein ubiquitination, the carbonylation of the proteins leads to their degradation by the proteasome system. However, unlike the enzymatic control of the ubiquitination by deubiquitinases, protein carbonylation is a nonenzymatic and irreversible post-translational modification. Similar to deubiquitinase enzymes, ALDHs could also be involved in counteracting the deactivation of specific signal transduction proteins by carbonylation. We advocate that future research should include these areas to advance our knowledge about the plant ALDH functions beyond stress and in gene signaling and plant development. 
Author Contributions: Writing—original draft preparation, T.D.M.; writing-review \& editing, A.J.T., A.J. and H.G.; funding acquisition, T.D.M. All authors have read and agreed to the published version of the manuscript.

Funding: This research was funded by the Natural Sciences and Engineering Research Council of Canada (NSERC), Discovery Grant Program, grant number DGECR-2019-00304. AJ received the Mitacs Globalink Graduate Fellowship.

Institutional Review Board Statement: Not applicable.

Informed Consent Statement: Not applicable.

Data Availability Statement: No new data were created in this study. Data sharing is not applicable to this article.

Conflicts of Interest: The authors declare no conflict of interest.

\section{References}

1. Farmer, E.E.; Davoine, C. Reactive electrophile species. Curr. Opin. Plant Biol. 2007, 10, 380-386. [CrossRef] [PubMed]

2. Mueller, M.J. Archetype signals in plants: The phytoprostanes. Curr. Opin. Plant Biol. 2004, 7, 441-448. [CrossRef] [PubMed]

3. Perozich, J.; Nicholas, H.; Wang, B.C.; Lindahl, R.; Hempel, J. Relationships within the aldehyde dehydrogenase extended family. Protein Sci. 2008, 8, 137-146. [CrossRef] [PubMed]

4. Vasiliou, V.; Bairoch, A.; Tipton, K.F.; Nebert, D.W. Eukaryotic aldehyde dehydrogenase (ALDH) genes: Human polymorphisms, and recommended nomenclature based on divergent evolution and chromosomal mapping. Pharmacogenetics 1999, 9, 421-434. [PubMed]

5. Sophos, N.A.; Vasiliou, V. Aldehyde dehydrogenase gene superfamily: The 2002 update. Chem. Biol. Interact. 2003, 143, 5-22. [CrossRef]

6. Vasiliou, V.; Nebert, D.W. Analysis and update of the human aldehyde dehydrogenase (ALDH) gene family. Hum. Genom. 2005, 2, 138-443. [CrossRef]

7. Cui, X.; Wise, R.P.; Schnable, P.S. The rf2 Nuclear Restorer Gene of Male-Sterile T-Cytoplasm Maize. Science 1996, $272,1334-1336$. [CrossRef]

8. Chen, T.H.; Murata, N. Enhancement of tolerance of abiotic stress by metabolic engineering of betaines and other compatible solutes. Curr. Opin. Plant Biol. 2002, 5, 250-257. [CrossRef]

9. Kirch, H.H.; Bartels, D.; Wei, Y.; Schnable, P.S.; Wood, A.J. The ALDH gene superfamily of Arabidopsis. Trends Plant Sci. 2004, 9, 371-377. [CrossRef]

10. Kotchoni, S.O.; Kuhns, C.; Ditzer, A.; Kirch, H.-H.; Bartels, D. Over-expression of different aldehyde dehydrogenase genes in Arabidopsis thaliana confers tolerance to abiotic stress and protects plants against lipid peroxidation and oxidative stress. Plant Cell Environ. 2006, 29, 1033-1048. [CrossRef]

11. Stiti, N.; Missihoun, T.D.; Kotchoni, S.O.; Kirch, H.-H.; Bartels, D. Aldehyde Dehydrogenases in Arabidopsis thaliana: Biochemical Requirements, Metabolic Pathways, and Functional Analysis. Front. Plant Sci. 2011, 2, 65. [CrossRef] [PubMed]

12. Shin, J.H.; Kim, S.R.; An, G. Rice Aldehyde Dehydrogenase7 Is Needed for Seed Maturation and Viability. Plant Physiol. 2008, 149, 905-915. [CrossRef] [PubMed]

13. Brocker, C.; Vasiliou, M.; Carpenter, S.; Carpenter, C.; Zhang, Y.; Wang, X.; Kotchoni, S.O.; Wood, A.J.; Kirch, H.H.; Kopečný, D.; et al. Aldehyde dehydrogenase (ALDH) superfamily in plants: Gene nomenclature and comparative genomics. Planta 2012, 237, 189-210. [CrossRef] [PubMed]

14. Wood, A.J.; Duff, R.J. The aldehyde dehydrogenase (ALDH) gene superfamily of the moss Physcomitrella patens and the algae Chlamydomonas reinhardtii and Ostreococcus tauri. Bryologist 2009, 112, 1-11. [CrossRef]

15. Valverde, F.; Losada, M.; Serrano-Delgado, A. Engineering a central metabolic pathway: Glycolysis with no net phosphorylation in an Escherichia coli gap mutant complemented with a plant GapN gene. FEBS Lett. 1999, 449, 153-158. [CrossRef]

16. Gao, Z.; Loescher, W.H. NADPH Supply and Mannitol Biosynthesis. Characterization, Cloning, and Regulation of the NonReversible Glyceraldehyde-3-Phosphate Dehydrogenase in Celery Leaves1. Plant Physiol. 2000, 124, 321-330. [CrossRef] [PubMed]

17. Marchitti, S.A.; Brocker, C.; Stagos, D.; Vasiliou, V. Non-P450 aldehyde oxidizing enzymes: The aldehyde dehydrogenase superfamily. Expert Opin. Drug Metab. Toxicol. 2008, 4, 697-720. [CrossRef] [PubMed]

18. Stiti, N.; Podgórska, K.; Bartels, D. Aldehyde dehydrogenase enzyme ALDH3H1 from Arabidopsis thaliana: Identification of amino acid residues critical for cofactor specificity. Biochim. Biophys. Acta BBA Proteins Proteom. 2014, 1844, 681-693. [CrossRef] [PubMed]

19. Fürst-Jansen, J.M.R.; de Vries, S.; de Vries, J. Evo-physio: On stress responses and the earliest land plants. J. Exp. Bot. 2020, 71, 3254-3269. [CrossRef]

20. Bowman, J.L.; Kohchi, T.; Yamato, K.T.; Grimwood, J.; Shu, S.; Ishizaki, K.; Yamaoka, S.; Nishihama, R.; Nakamura, Y.; Berger, F.; et al. Insights into Land Plant Evolution Garnered from the Marchantia polymorpha Genome. Cell 2017, 171, 287-304.e15. [CrossRef] 
21. Li, F.; Brouwer, P.; Carretero-Paulet, L.; Cheng, S.; De Vries, J.; Delaux, P.-M.; Eily, A.; Koppers, N.; Kuo, L.; Li, Z.; et al. Fern genomes elucidate land plant evolution and cyanobacterial symbioses. Nat. Plants 2018, 4, 460-472. [CrossRef] [PubMed]

22. Li, F.; Nishiyama, T.; Waller, M.; Frangedakis, E.; Keller, J.; Li, Z.; Fernandez-Pozo, N.; Barker, M.S.; Bennett, T.; Blázquez, M.A.; et al. Anthoceros genomes illuminate the origin of land plants and the unique biology of hornworts. Nat. Plants 2020, 6, 259-272. [CrossRef] [PubMed]

23. Blanc-Mathieu, R.; Verhelst, B.; Derelle, E.; Rombauts, S.; Bouget, F.-Y.; Carré, I.; Château, A.; Eyre-Walker, A.; Grimsley, N.; Moreau, H.; et al. An improved genome of the model marine alga Ostreococcus tauri unfolds by assessing Illumina de novo assemblies. BMC Genom. 2014, 15, 1-12. [CrossRef]

24. Prochnik, S.E.; Umen, J.G.; Nedelcu, A.M.; Hallmann, A.; Miller, S.M.; Nishii, I.; Ferris, P.; Kuo, A.; Mitros, T.; Fritz-Laylin, L.K.; et al. Genomic Analysis of Organismal Complexity in the Multicellular Green Alga Volvox carteri. Science 2010, 329, 223-226. [CrossRef]

25. Merchant, S.S.; Prochnik, S.E.; Vallon, O.; Harris, E.H.; Karpowicz, S.J.; Witman, G.B.; Terry, A.; Salamov, A.; Fritz-Laylin, L.K.; Maréchal-Drouard, L.; et al. The Chlamydomonas Genome Reveals the Evolution of Key Animal and Plant Functions. Science 2007, 318, 245-250. [CrossRef] [PubMed]

26. Gao, B.; Zhang, D.; Li, X.; Yang, H.; Wood, A.J. De novo assembly and characterization of the transcriptome in the desiccationtolerant moss Syntrichia caninervis. BMC Res. Notes 2014, 7, 490. [CrossRef]

27. Rensing, S.A.; Lang, D.; Zimmer, A.D.; Terry, A.; Salamov, A.; Shapiro, H.; Nishiyama, T.; Perroud, P.-F.; Lindquist, E.; Kamisugi, Y.; et al. The Physcomitrella Genome Reveals Evolutionary Insights into the Conquest of Land by Plants. Science 2007, 319, 64-69. [CrossRef] [PubMed]

28. Kaul, K.; Koo, H.K.; Jenkins, J.; Rizzo, M.; Rooney, M.; Tallon, L.J.; Feldblyum, T.; Nierman, W.; Benito, M.I.; Lin, X.; et al. The Arabidopsis Genome Initiative. Analysis of the genome sequence of the flowering plant Arabidopsis thaliana. Nature 2000, 408, 796-815.

29. Yang, R.; Jarvis, D.E.; Chen, H.; Beilstein, M.A.; Grimwood, J.; Grimwood, J.; Shu, S.; Prochnik, S.; Xin, M.; Ma, C.; et al. The Reference Genome of the Halophytic Plant Eutrema salsugineum. Front. Plant Sci. 2013, 4, 46. [CrossRef]

30. Paterson, A.H.; Bowers, J.E.; Bruggmann, R.; Dubchak, I.; Grimwood, J.; Gundlach, H.; Haberer, G.; Hellsten, U.; Mitros, T.; Poliakov, A.; et al. The Sorghum bicolor genome and the diversification of grasses. Nature 2009, 457, 551-556. [CrossRef]

31. Wu, J.; Maehara, T.; Shimokawa, T.; Yamamoto, S.; Harada, C.; Takazaki, Y.; Ono, N.; Mukai, Y.; Koike, K.; Yazaki, J.; et al. A Comprehensive Rice Transcript Map Containing 6591 Expressed Sequence Tag Sites. Plant Cell 2002, 14, 525-535. [CrossRef] [PubMed]

32. Chen, M.; Presting, G.; Barbazuk, W.B.; Goicoechea, J.L.; Blackmon, B.; Fang, G.; Kim, H.; Frisch, D.; Yu, Y.; Sun, S.; et al. An Integrated Physical and Genetic Map of the Rice Genome. Plant Cell 2002, 14, 537-545. [CrossRef] [PubMed]

33. Zhang, G.; Liu, X.; Quan, Z.; Cheng, S.; Xu, X.; Pan, S.; Xie, M.; Zeng, P.; Yue, Z.; Wang, W.; et al. Genome sequence of foxtail millet (Setaria italica) provides insights into grass evolution and biofuel potential. Nat. Biotechnol. 2012, 30, 549-554. [CrossRef] [PubMed]

34. Jiao, Y.; Peluso, P.; Shi, J.; Liang, T.; Stitzer, M.C.; Wang, B.; Campbell, M.S.; Stein, J.C.; Wei, X.; Chin, C.-S.; et al. Improved maize reference genome with single-molecule technologies. Nat. Cell Biol. 2017, 546, 524-527. [CrossRef]

35. Banks, J.A.; Nishiyama, T.; Hasebe, M.; Bowman, J.L.; Gribskov, M.; Depamphilis, C.W.; Albert, V.A.; Aono, N.; Aoyama, T.; Ambrose, B.A.; et al. The Selaginella Genome Identifies Genetic Changes Associated with the Evolution of Vascular Plants. Science 2011, 332, 960-963. [CrossRef]

36. Jaillon, O.; Aury, J.-M.; Noel, B.; Policriti, A.; Clepet, C.; Casagrande, A.; Choisne, N.; Aubourg, S.; Vitulo, N.; Jubin, C.; et al. The grapevine genome sequence suggests ancestral hexaploidization in major angiosperm phyla. Nature 2007, 449, $463-467$.

37. Tuskan, G.A.; DiFazio, S.; Jansson, S.; Bohlmann, J.; Grigoriev, I.; Hellsten, U.; Putnam, N.; Ralph, S.; Rombauts, S.; Salamov, A.; et al. The Genome of Black Cottonwood, Populus trichocarpa (Torr. \& Gray). Science 2006, 313, 1596-1604. [CrossRef]

38. Zhang, L.; Cai, X.; Wu, J.; Liu, M.; Grob, S.; Cheng, F.; Liang, J.; Cai, C.; Liu, Z.; Liu, B.; et al. Improved Brassica rapa reference genome by single-molecule sequencing and chromosome conformation capture technologies. Hortic. Res. 2018, 5, 517. [CrossRef]

39. The Tomato Genome Consortium. The tomato genome sequence provides insights into fleshy fruit evolution. Nature 2012, 485, 635-641. [CrossRef]

40. Paterson, A.H.; Wendel, J.F.; Gundlach, H.; Guo, H.; Jenkins, J.; Jin, D.; Llewellyn, D.; Showmaker, K.C.; Shu, S.; Udall, J.; et al. Repeated polyploidization of Gossypium genomes and the evolution of spinnable cotton fibres. Nat. Cell Biol. 2012, $492,423-427$. [CrossRef]

41. Daccord, N.; Celton, J.-M.; Linsmith, G.; Becker, C.; Choisne, N.; Schijlen, E.; Van De Geest, H.; Bianco, L.; Micheletti, D.; Velasco, R.; et al. High-quality de novo assembly of the apple genome and methylome dynamics of early fruit development. Nat. Genet. 2017, 49, 1099-1106. [CrossRef] [PubMed]

42. Xie, M.; Chung, C.Y.L.; Li, M.W.; Wong, F.L.; Wang, X.; Liu, A.; Wang, Z.; Leung, A.K.Y.; Wong, T.H.; Tong, S.W.; et al. A reference-grade wild soybean genome. Nat. Commun. 2019, 10, 1-12. [CrossRef] [PubMed]

43. Stiti, N.; Adewale, I.O.; Petersen, J.; Bartels, D.; Kirch, H.-H. Engineering the nucleotide coenzyme specificity and sulfhydryl redox sensitivity of two stress-responsive aldehyde dehydrogenase isoenzymes of Arabidopsis thaliana. Biochem. J. 2011, 434, 459-471. [CrossRef] [PubMed] 
44. Belmont-Díaz, J.A.; Yoval-Sánchez, B.; Calleja-Castañeda, L.F.; Pardo Vázquez, J.P.; Rodríguez-Zavala, J.S. Alda-1 modulates the kinetic properties of mitochondrial aldehyde dehydrogenase (ALDH2). FEBS J. 2016, 283, 3637-3650. [CrossRef]

45. Muñoz-Clares, R.; Casanova-Figueroa, K. The importance of assessing aldehyde substrate inhibition for the correct determination of kinetic parameters and mechanisms: The case of the ALDH enzymes. Chem. Interact. 2019, 305, 86-97. [CrossRef]

46. Stiti, N.; Chandrasekar, B.; Strubl, L.; Mohammed, S.; Bartels, D.; Van Der Hoorn, R.A.L. Nicotinamide Cofactors Suppress Active-Site Labeling of Aldehyde Dehydrogenases. ACS Chem. Biol. 2016, 11, 1578-1586. [CrossRef]

47. Nair, R.B.; Bastress, K.L.; Ruegger, M.O.; Denault, J.W.; Chapple, C. The Arabidopsis thaliana REDUCED EPIDERMAL FLUORESCENCE1 Gene Encodes an Aldehyde Dehydrogenase Involved in Ferulic Acid and Sinapic Acid Biosynthesis. Plant Cell 2004, 16, 544-554. [CrossRef]

48. Liu, F.; Schnable, P.S. Functional Specialization of Maize Mitochondrial Aldehyde Dehydrogenases. Plant Physiol. 2002, 130, 1657-1674. [CrossRef]

49. Xie, J.; Deng, L.; Zhou, Y.; Yao, S.; Zeng, K. Analysis of changes in volatile constituents and expression of genes involved in terpenoid metabolism in oleocellosis peel. Food Chem. 2018, 243, 269-276. [CrossRef]

50. Werbrouck, S.P.O.; Strnad, M.; Van Onckelen, H.A.; DeBergh, P.C. Meta-topolin, an alternative to benzyladenine in tissue culture? Physiol. Plant. 2008, 98, 291-297. [CrossRef]

51. Schwab, W.; Davidovich-Rikanati, R.; Lewinsohn, E. Biosynthesis of plant-derived flavor compounds. Plant J. 2008, 54, 712-732. [CrossRef] [PubMed]

52. Graser, G.; Oldham, N.J.; Brown, P.D.; Temp, U.; Gershenzon, J. The biosynthesis of benzoic acid glucosinolate esters in Arabidopsis thaliana. Phytochemistry 2001, 57, 23-32. [CrossRef]

53. Boatright, J.; Negre, F.; Chen, X.; Kish, C.M.; Wood, B.; Peel, G.; Orlova, I.; Gang, D.; Rhodes, D.; Dudareva, N. Understanding in Vivo Benzenoid Metabolism in Petunia Petal Tissue. Plant Physiol. 2004, 135, 1993-2011. [CrossRef] [PubMed]

54. Long, M.C.; Nagegowda, D.A.; Kaminaga, Y.; Ho, K.K.; Kish, C.M.; Schnepp, J.; Sherman, D.; Weiner, H.; Rhodes, D.; Dudareva, N Involvement of snapdragon benzaldehyde dehydrogenase in benzoic acid biosynthesis. Plant J. 2009, 59, 256-265. [CrossRef] [PubMed]

55. Frömmel, J.; Končitíková, R.; Kopečný, D.; Soural, M.; Šebela, M. Oxidation of imidazole- and pyrazole-derived aldehydes by plant aldehyde dehydrogenases from the family 2 and 10. Chem. Biol. Interact. 2019, 304, 194-201. [CrossRef]

56. Missihoun, T.D.; Kotchoni, S.O.; Bartels, D. Active Sites of Reduced Epidermal Fluorescence1 (REF1) Isoforms Contain Amino Acid Substitutions That Are Different between Monocots and Dicots. PLoS ONE 2016, 11, e0165867. [CrossRef]

57. Liu, F. Mitochondrial Aldehyde Dehydrogenase Activity Is Required for Male Fertility in Maize. Plant Cell Online 2001, 13, 1063-1078. [CrossRef]

58. Xie, X.; Zhang, Z.; Zhao, Z.; Xie, Y.; Li, H.; Ma, X.; Liu, Y.G.; Chen, L. The mitochondrial aldehyde dehydrogenase OsALDH2b negatively regulates tapetum degeneration in rice. J. Exp. Bot. 2020, 71, 2551-2560. [CrossRef]

59. Gómez-Gómez, L.; Pacios, L.F.; Díaz-Perales, A.; Garrido-Arandia, M.; Argandoña, J.; Rubio-Moraga, A.; Ahrazem, O. Expression and Interaction Analysis among Saffron ALDHs and Crocetin Dialdehyde. Int. J. Mol. Sci. 2018, 19, 1409. [CrossRef]

60. Demurtas, O.C.; Frusciante, S.; Ferrante, P.; Diretto, G.; Azad, N.H.; Pietrella, M.; Aprea, G.; Taddei, A.R.; Romano, E.; Mi, J.; et al. Candidate Enzymes for Saffron Crocin Biosynthesis Are Localized in Multiple Cellular Compartments. Plant Physiol. 2018, 177, 990-1006. [CrossRef]

61. Rajangam, A.S.; Gidda, S.K.; Craddock, C.; Mullen, R.T.; Dyer, J.M.; Eastmond, P.J. Molecular Characterization of the Fatty Alcohol Oxidation Pathway for Wax-Ester Mobilization in Germinated Jojoba Seeds1[W]. Plant Physiol. 2012, 161, 72-80. [CrossRef] [PubMed]

62. Liu, T.; Dong, C.; Qi, M.; Zhang, B.; Huang, L.; Xu, Z.; Lian, J. Construction of a Stable and Temperature-Responsive Yeast Cell Factory for Crocetin Biosynthesis Using CRISPR-Cas9. Front. Bioeng. Biotechnol. 2020, 8, 653. [CrossRef] [PubMed]

63. Bouché, N.; Fait, A.; Bouchez, D.; Møller, S.G.; Fromm, H. Mitochondrial succinic-semialdehyde dehydrogenase of the gammaaminobutyrate shunt is required to restrict levels of reactive oxygen intermediates in plants. Proc. Natl. Acad. Sci. USA 2003, 100, 6843-6848. [CrossRef] [PubMed]

64. Bown, A.W.; Shelp, B.J. The Metabolism and Functions of [gamma]-Aminobutyric Acid. Plant Physiol. 1997, 115, 1-5. [CrossRef] [PubMed]

65. Hildebrandt, T.M.; Nunes-Nesi, A.; Araújo, W.L.; Braun, H.-P. Amino Acid Catabolism in Plants. Mol. Plant 2015, 8, 1563-1579. [CrossRef] [PubMed]

66. Tanaka, N.; Takahashi, H.; Kitano, H.; Matsuoka, M.; Akao, S.; Uchimiya, H.; Komatsu, S. Proteome Approach to Characterize the Methylmalonate-Semialdehyde Dehydrogenase that Is Regulated by Gibberellin. J. Proteome Res. 2005, 4, 1575-1582. [CrossRef]

67. Končitíková, R.; Vigouroux, A.; Kopečná, M.; Andree, T.; Bartoš, J.; Šebela, M.; Moréra, S.; Kopečný, D. Role and structural characterization of plant aldehyde dehydrogenases from family 2 and family 7. Biochem. J. 2015, 468, 109-123. [CrossRef]

68. Missihoun, T.D.; Hou, Q.; Mertens, D.; Bartels, D. Sequence and functional analyses of the aldehyde dehydrogenase 7B4 gene promoter in Arabidopsis thaliana and selected Brassicaceae: Regulation patterns in response to wounding and osmotic stress. Planta 2014, 239, 1281-1298. [CrossRef]

69. Zhao, J.; Missihoun, T.D.; Bartels, D. The role of Arabidopsis aldehyde dehydrogenase genes in response to high temperature and stress combinations. J. Exp. Bot. 2017, 68, 4295-4308. [CrossRef] 
70. Gil-Monreal, M.; Zabalza, A.; Missihoun, T.D.; Dörmann, P.; Bartels, D.; Royuela, M. Induction of the PDH bypass and upregulation of the ALDH7B4 in plants treated with herbicides inhibiting amino acid biosynthesis. Plant Sci. 2017, 264, 16-28. [CrossRef]

71. Li, X.; Huang, L.; Lu, J.; Cheng, Y.; You, Q.; Wang, L.; Song, X.; Zhou, X.; Jiao, Y. Large-Scale Investigation of Soybean Gene Functions by Overexpressing a Full-Length Soybean cDNA Library in Arabidopsis. Front. Plant Sci. 2018, 9, 631. [CrossRef] [PubMed]

72. Chen, T.H.H.; Murata, N. Glycinebetaine protects plants against abiotic stress: Mechanisms and biotechnological applications Plant Cell Environ. 2010, 34, 1-20. [CrossRef] [PubMed]

73. Zarei, A.; Trobacher, C.P.; Shelp, B.J. Arabidopsis aldehyde dehydrogenase 10 family members confer salt tolerance through putrescine-derived 4-aminobutyrate (GABA) production. Sci. Rep. 2016, 6, 35115. [CrossRef] [PubMed]

74. Bradbury, L.M.T.; Gillies, S.A.; Brushett, D.J.; Waters, D.L.E.; Henry, R.J. Inactivation of an aminoaldehyde dehydrogenase is responsible for fragrance in rice. Plant Mol. Biol. 2008, 68, 439-449. [CrossRef] [PubMed]

75. Rippa, S.; Zhao, Y.; Merlier, F.; Charrier, A.; Perrin, Y. Plant Physiology and Biochemistry The carnitine biosynthetic pathway in Arabidopsis thaliana shares similar features with the pathway of mammals and fungi. Plant Physiol. Biochem. 2012, 60, 109-114. [CrossRef] [PubMed]

76. Frömmel, J.; Tarkowski, P.; Kopečný, D.; Šebela, M. The use of tomato aminoaldehyde dehydrogenase 1 for the detection of aldehydes in fruit distillates. New Biotechnol. 2016, 33, 666-675.

77. Kopečný, D.; Tylichová, M.; Snégaroff, J.; Popelková, H.; Šebela, M. Carboxylate and aromatic active-site residues are determinants of high-affinity binding of $\omega$-aminoaldehydes to plant aminoaldehyde dehydrogenases. FEBS J. 2011, 278, 3130-3139. [CrossRef]

78. Kopečny, D.; Končitíková, R.; Tylichová, M.; Vigouroux, A.; Moskalíková, H.; Soural, M.; Šebela, M.; Moréra, S. Plant ALDH10 family: Identifying critical residues for substrate specificity and trapping a thiohemiacetal intermediate. J. Biol. Chem. 2013, 288, 9491-9507. [CrossRef]

79. Frömmel, J.; Šebela, M.; Demo, G.; Lenobel, R.; Pospisil, T.; Soural, M.; Kopečný, D. N-acyl- $\omega$-aminoaldehydes are efficient substrates of plant aminoaldehyde dehydrogenases. Amino Acids 2014, 47, 175-187. [CrossRef]

80. Fitzgerald, T.L.; Le Waters, D.; Henry, R.J. Betaine aldehyde dehydrogenase in plants. Plant Biol. 2009, 11, 119-130. [CrossRef]

81. Missihoun, T.D.; Schmitz, J.; Klug, R.; Kirch, H.-H.; Bartels, D. Betaine aldehyde dehydrogenase genes from Arabidopsis with different sub-cellular localization affect stress responses. Planta 2011, 233, 369-382. [CrossRef] [PubMed]

82. Missihoun, T.D.; Willée, E.; Guegan, J.P.; Berardocco, S.; Shafiq, M.R.; Bouchereau, A.; Bartels, D. Overexpression ofALDH10A8andALDH10A9Genes Provides Insight into Their Role in Glycine Betaine Synthesis and Affects Primary Metabolism inArabidopsis thaliana. Plant Cell Physiol. 2015, 56, 1798-1807. [CrossRef] [PubMed]

83. Díaz-Sánchez, Ángel, G.; González-Segura, L.; Mújica-Jiménez, C.; Rudiño-Piñera, E.; Montiel, C.; Martínez-Castilla, L.P.; Muñoz-Clares, R. Amino Acid Residues Critical for the Specificity for Betaine Aldehyde of the Plant ALDH10 Isoenzyme Involved in the Synthesis of Glycine Betaine. Plant Physiol. 2012, 158, 1570-1582. [CrossRef]

84. Muñoz-Clares, R.; Riveros-Rosas, H.; Garza-Ramos, G.; González-Segura, L.; Mújica-Jiménez, C.; Julián-Sánchez, A. Exploring the evolutionary route of the acquisition of betaine aldehyde dehydrogenase activity by plant ALDH10 enzymes: Implications for the synthesis of the osmoprotectant glycine betaine. BMC Plant Biol. 2014, 14, 149. [CrossRef] [PubMed]

85. Jacques, F.; Zhao, Y.; Kopečná, M.; Končitíková, R.; Kopečný, D.; Rippa, S.; Perrin, Y. Roles for ALDH10 enzymes in $\gamma$ butyrobetaine synthesis, seed development, germination, and salt tolerance in Arabidopsis. J. Exp. Bot. 2020. [CrossRef]

86. Plaxton, W.C. The organizatiom and regulation of plant glycolysis. Annu. Rev. Plant Physiol. Plant Mol. Biol. 1996, 47, 185-214. [CrossRef]

87. Rius, S.P.; Fernie, A.; Iglesias, A.A.; Gomez-Casati, D.F. Characterization of an Arabidopsis thaliana mutant lacking a cytosolic non-phosphorylating glyceraldehyde-3-phosphate dehydrogenase. Plant Mol. Biol. 2006, 61, 945-957. [CrossRef]

88. Kishor, P.B.K.; Kumari, P.H.; Sunita, M.S.L.; Sreenivasulu, N. Role of proline in cell wall synthesis and plant development and its implications in plant ontogeny. Front. Plant Sci. 2014, 6, 544. [CrossRef]

89. Trovato, M.; Forlani, G.; Signorelli, S.; Funck, D. Proline Metabolism and Its Functions in Development and Stress Tolerance. In Osmoprotectant-Mediated Abiotic Stress Tolerance in Plants; Springer: Berlin/Heidelberg, Germany, $2019 ;$ pp. 41-72.

90. Mattioli, R.; Biancucci, M.; El Shall, A.; Mosca, L.; Costantino, P.; Funck, D.; Trovato, M. Proline synthesis in developing microspores is required for pollen development and fertility. BMC Plant Biol. 2018, 18, 1-15. [CrossRef]

91. Mattioli, R.; Biancucci, M.; Lonoce, C.; Costantino, P.; Trovato, M. Proline is required for male gametophyte development in Arabidopsis. BMC Plant Biol. 2012, 12, 236. [CrossRef]

92. Wang, G.; Zhang, J.; Wang, G.; Fan, X.; Sun, X.; Qin, H.; Xu, N.; Zhong, M.; Qiao, Z.; Tang, Y.; et al. Proline responding1 Plays a Critical Role in Regulating General Protein Synthesis and the Cell Cycle in Maize. Plant Cell 2014, 26, 2582-2600. [CrossRef] [PubMed]

93. Mattioli, R.; Falasca, G.; Sabatini, S.; Altamura, M.M.; Costantino, P.; Trovato, M. The proline biosynthetic genes P5CS1 and P5CS2 play overlapping roles in Arabidopsis flower transition but not in embryo development. Physiol. Plant. 2009, 137, 72-85. [CrossRef] [PubMed]

94. Székely, G. Duplicated P5CS genes of Arabidopsis play distinct roles in stress regulation and developmental control of proline biosynthesis. Plant J. 2008, 53, 11-28. [CrossRef] [PubMed] 
95. Korasick, D.A.; Končitíková, R.; Kopečná, M.; Hájková, E.; Vigouroux, A.; Moréra, S.; Becker, D.F.; Šebela, M.; Tanner, J.J.; Kopečný, D. Structural and Biochemical Characterization of Aldehyde Dehydrogenase 12, the Last Enzyme of Proline Catabolism in Plants. J. Mol. Biol. 2019, 431, 576-592. [CrossRef]

96. García-Ríos, M.; Fujita, T.; LaRosa, P.C.; Locy, R.D.; Clithero, J.M.; Bressan, R.A.; Csonka, L.N. Cloning of a polycistronic cDNA from tomato encoding -glutamyl kinase and -glutamyl phosphate reductase. Proc. Natl. Acad. Sci. USA 1997, 94, 8249-8254. [CrossRef]

97. Jimenez-Lopez, J.C.; Lopez-Valverde, F.J.; Robles-Bolivar, P.; Lima-Cabello, E.; Gachomo, E.W.; Kotchoni, S.O. Genome-Wide Identification and Functional Classification of Tomato (Solanum lycopersicum) Aldehyde Dehydrogenase (ALDH) Gene Superfamily. PLoS ONE 2016, 11, e0164798. [CrossRef]

98. Rai, A.N.; Penna, S. Molecular evolution of plant P5CS gene involved in proline biosynthesis. Mol. Biol. Rep. 2013, 40, 6429-6435. [CrossRef]

99. Kesari, R.; Lasky, J.R.; Villamor, J.G.; Marais, D.L.D.; Chen, Y.-J.C.; Liu, T.W.; Lin, W.; Juenger, T.E.; Verslues, P.E. Intron-mediated alternative splicing of Arabidopsis P5CS1 and its association with natural variation in proline and climate adaptation. Proc. Natl. Acad. Sci. USA 2012, 109, 9197-9202. [CrossRef]

100. Hare, P.; Cress, W.; Van Staden, J. A regulatory role for proline metabolism in stimulating Arabidopsis thaliana seed germination. Plant Growth Regul. 2003, 39, 41-50. [CrossRef]

101. Nanjo, T.; Kobayashi, M.; Yoshiba, Y.; Sanada, Y.; Wada, K.; Tsukaya, H.; Shinozaki, K. Biological functions of proline in morphogenesis and osmotolerance revealed in antisense transgenic Ara-bidopsis thaliana. Plant J. 1999, 18, 185-193. [CrossRef]

102. Guan, C.; Huang, Y.H.; Cui, X.; Liu, S.J.; Zhou, Y.Z.; Zhang, Y. Overexpression of gene encoding the key enzyme involved in proline-biosynthesis (PuP5CS) to improve salt tolerance in switchgrass (Panicum virgatum L.). Plant Cell Rep. 2018, 37, 1187-1199. [CrossRef] [PubMed]

103. Mattioli, R.; Marchese, D.; D'Angeli, S.; Altamura, M.M.; Costantino, P.; Trovato, M. Modulation of intracellular proline levels affects flowering time and inflorescence architecture in Ara-bidopsis. Plant Mol. Biol. 2008, 66, 277-288. [CrossRef] [PubMed]

104. Yang, H.; Zhang, D.; Wang, J.; Wood, A.J.; Zhang, Y. Molecular cloning of a stress-responsive aldehyde dehydrogenase gene ScALDH21 from the desiccation-tolerant moss Syntrichia caninervis and its responses to different stresses. Mol. Biol. Rep. 2011, 39, 2645-2652. [CrossRef] [PubMed]

105. Chen, X.; Zeng, Q.; Wood, A.J. The stress-responsive Tortula ruralis gene ALDH21A1 describes a novel eukaryotic al-dehyde dehydrogenase protein family. J. Plant Physiol. 2002, 159, 677-684. [CrossRef]

106. Kopečná, M.; Vigouroux, A.; Vilím, J.; Končitíková, R.; Briozzo, P.; Hájková, E.; Jašková, L.; Von Schwartzenberg, K.; Šebela, M.; Moréra, S.; et al. The ALDH21 gene found in lower plants and some vascular plants codes for a NADP+-dependent succinic semialdehyde dehydrogenase. Plant J. 2017, 92, 229-243. [CrossRef]

107. Toyokura, K.; Watanabe, K.; Oiwaka, A.; Kusano, M.; Tameshige, T.; Tatematsu, K.; Matsumoto, N.; Tsugeki, R.; Saito, K.; Okada, K. Succinic Semialdehyde Dehydrogenase is Involved in the Robust Patterning of Arabidopsis Leaves along the AdaxialAbaxial Axis. Plant Cell Physiol. 2011, 52, 1340-1353. [CrossRef]

108. Yang, H.; Zhang, D.; Li, H.; Dong, L.; Lan, H. Ectopic overexpression of the aldehyde dehydrogenase ALDH21 from Syntrichia caninervis in tobacco confers salt and drought stress tolerance. Plant Physiol. Biochem. 2015, 95, 83-91. [CrossRef]

109. Yang, H.; Zhang, D.; Li, X.; Li, H.; Zhang, D.; Lan, H.; Wood, A.J.; Wang, J. Overexpression of ScALDH21 gene in cotton improves drought tolerance and growth in greenhouse and field conditions. Mol. Breed. 2016, 36, 1-13. [CrossRef]

110. Kirch, H.-H.; Schlingensiepen, S.; Kotchoni, S.; Sunkar, R.; Bartels, D. Detailed expression analysis of selected genes of the aldehyde dehydrogenase (ALDH) gene superfamily in Arabidopsis thaliana. Plant Mol. Biol. 2005, 57, 315-332. [CrossRef]

111. Olsen, A.N.; Ernst, H.A.; Leggio, L.L.; Skriver, K. NAC transcription factors: Structurally distinct, functionally diverse. Trends Plant Sci. 2005, 10, 79-87. [CrossRef]

112. Nakashima, K.; Takasaki, H.; Mizoi, J.; Shinozaki, K.; Yamaguchi-Shinozaki, K. NAC transcription factors in plant abiotic stress responses. Biochim. Biophys. Acta (BBA)-Bioenerg. 2012, 1819, 97-103. [CrossRef] [PubMed]

113. Zhao, J.; Missihoun, T.D.; Bartels, D. The ATAF1 transcription factor is a key regulator of aldehyde dehydrogenase 7B4 (ALDH7B4) gene expression in Arabidopsis thaliana. Planta 2018, 248, 1017-1027. [CrossRef] [PubMed]

114. Missihoun, T.D.; Kirch, H.H.; Bartels, D. T-DNA insertion mutants reveal complex expression patterns of the aldehyde dehydrogenase 3H1 locus in Arabidopsis thaliana. J. Exp. Bot. 2012, 63, 3887-3898. [CrossRef] [PubMed]

115. Zhang, Y.; Mao, L.; Wang, H.; Brocker, C.; Yin, X.; Vasiliou, V.; Fei, Z.; Wang, X. Genome-Wide Identification and Analysis of Grape Aldehyde Dehydrogenase (ALDH) Gene Superfamily. PLoS ONE 2012, 7, e32153. [CrossRef] [PubMed]

116. Guo, J.; Sun, W.; Liu, H.; Chi, J.; Odiba, A.S.; Li, G.; Li-Ping, J.; Xin, C. Aldehyde dehydrogenase plays crucial roles in response to lower temperature stress in Solanum tuberosum and Nicotiana benthamiana. Plant Sci. 2020, 297, 110525. [CrossRef] [PubMed]

117. Stiti, N.; Podgórska, K.A.; Bartels, D. S-Nitrosation impairs activity of stress-inducible aldehyde dehydrogenases from Arabidopsis thaliana. Plant Sci. 2020, 292, 110389. [CrossRef]

118. Mano, J.; Nagata, M.; Okamura, S.; Shiraya, T.; Mitsui, T. Identification of Oxidatively Modified Proteins in Salt-Stressed Arabidopsis: A Carbonyl-Targeted Proteomics Approach. Plant Cell Physiol. 2014, 55, 1233-1244. [CrossRef]

119. Rasheed, S.; Bashir, K.; Kim, J.M.; Ando, M.; Tanaka, M.; Seki, M. The modulation of acetic acid pathway genes in Arabidopsis improves survival under drought stress. Sci. Rep. 2018, 8, 1-15. [CrossRef] 
120. Rodrigues, S.M.; Andrade, M.O.; Gomes, A.P.S.; DaMatta, F.M.; Baracat-Pereira, M.C.; Fontes, E.P.B. Arabidopsis and tobacco plants ectopically expressing the soybean antiquitin-like ALDH7 gene display enhanced tolerance to drought, salinity, and oxidative stress. J. Exp. Bot. 2006, 57, 1909-1918. [CrossRef]

121. Huang, W.; Ma, X.; Wang, Q.; Gao, Y.; Xue, Y.; Niu, X.; Yu, G.; Liu, Y.-S. Significant improvement of stress tolerance in tobacco plants by overexpressing a stress-responsive aldehyde dehydrogenase gene from maize (Zea mays). Plant Mol. Biol. 2008, 68, 451-463. [CrossRef]

122. Chen, J.; Wei, B.; Li, G.; Fan, R.; Zhong, Y.; Wang, X.; Zhang, X. TraeALDH7B1-5A, encoding aldehyde dehydrogenase 7 in wheat, confers improved drought tolerance in Arabidopsis. Planta 2015, 242, 137-151. [CrossRef] [PubMed]

123. Gautam, R.; Meena, R.K.; Woch, N.; Kirti, P. Ectopic expression of BrALDH7B2 gene encoding an antiquitin from Brassica rapa confers tolerance to abiotic stresses and improves photosynthetic performance under salt stress in tobacco. Environ. Exp. Bot. 2020, 180, 104223. [CrossRef]

124. Vries, J.; de Vries, S.; Curtis, B.A.; Zhou, H.; Penny, S.; Feussner, K.; Pinto, D.M.; Steinert, M.; Cohen, A.M.; von Schwartzenberg, K.; et al. Heat stress response in the closest algal relatives of land plants reveals conserved stress signaling circuits. Plant J. 2020, 103, 1025-1048. [CrossRef] [PubMed]

125. Sunkar, R.; Bartels, D.; Kirch, H.H. Overexpression of a stress-inducible aldehyde dehydrogenase gene from Arabidopsis thaliana in transgenic plants improves stress tolerance. Plant J. 2003, 35, 452-464. [CrossRef] [PubMed]

126. Noctor, G.; Mhamdi, A.; Chaouch, S.; Han, Y.; Neukermans, J.; Marquez-Garcia, B.; Queval, G.; Foyer, C.H. Glutathione in plants: An integrated overview. Plant Cell Environ. 2011, 35, 454-484. [CrossRef] [PubMed]

127. Dutilleul, C.; Lelarge, C.; Prioul, J.L.; De Paepe, R.; Foyer, C.H.; Noctor, G. Mitochondria-Driven Changes in Leaf NAD Status Exert a Crucial Influence on the Control of Nitrate Assimilation and the Integration of Carbon and Nitrogen Metabolism. Plant Physiol. 2005, 139, 64-78. [CrossRef] [PubMed]

128. Geigenberger, P.; Fernie, A.R. Metabolic Control of Redox and Redox Control of Metabolism in Plants. Antioxid. Redox Signal. 2014, 21, 1389-1421. [CrossRef]

129. Shen, W.; Wei, Y.; Dauk, M.; Tan, Y.; Taylor, D.C.; Selvaraj, G.; Zou, J. Involvement of a glycerol-3-phosphate dehydrogenase in modulating the NADH/NAD+ ratio provides ev-idence of a mitochondrial glycerol-3-phosphate shuttle in Arabidopsis. Plant Cell 2006, 18, 422-441. [CrossRef]

130. Sweetlove, L.J.; Lytovchenko, A.; Morgan, M.; Nunes-Nesi, A.; Taylor, N.L.; Baxter, C.J.; Eickmeier, I.; Fernie, A.R. Mitochondrial uncoupling protein is required for efficient photosynthesis. Proc. Natl. Acad. Sci. USA 2006, 103, 19587-19592. [CrossRef]

131. Missihoun, T.D.; Kotchoni, S.O.; Bartels, D. Aldehyde Dehydrogenases Function in the Homeostasis of Pyridine Nucle-otides in Arabidopsis thaliana. Sci. Rep. 2018, 8, 2936. [CrossRef]

132. Missihoun, T.D.; Kotchoni, S.O. Aldehyde dehydrogenases and the hypothesis of a glycolaldehyde shunt pathway of photorespiration. Plant Signal. Behav. 2018, 13, e1449544-10. [CrossRef] [PubMed]

133. Mano, J.; Torii, Y.; Hayashi, S.I.; Takimoto, K.; Matsui, K.; Nakamura, K.; Inzé, D.; Babiychuk, E.; Kushnir, S.; Asada, K. The NADPH:Quinone Oxidoreductase P1- $\zeta$-crystallin in Arabidopsis Catalyzes the $\alpha, \beta$-Hydrogenation of 2-Alkenals: Detoxication of the Lipid Peroxide-Derived Reactive Aldehydes. Plant Cell Physiol. 2002, 43, 1445-1455. [CrossRef] [PubMed]

134. Sengupta, D.; Naik, D.; Reddy, A.R. Plant aldo-keto reductases (AKRs) as multi-tasking soldiers involved in diverse plant metabolic processes and stress defense: A structure-function update. J. Plant Physiol. 2015, 179, 40-55. [CrossRef] [PubMed]

135. Yamauchi, Y.; Hasegawa, A.; Taninaka, A.; Mizutani, M.; Sugimoto, Y. NADPH-dependent Reductases Involved in the Detoxification of Reactive Carbonyls in Plants. J. Biol. Chem. 2010, 286, 6999-7009. [CrossRef] [PubMed]

136. Pawłowski, T.A.; Staszak, A.; Karolewski, P.; Giertych, M.J. Plant development reprogramming by cynipid gall wasp: Proteomic analysis. Acta Physiol. Plant. 2017, 39, 114. [CrossRef]

137. Saini, S.S.; Teotia, D.; Gaid, M.; Thakur, A.; Beerhues, L.; Sircar, D. Benzaldehyde dehydrogenase-driven phytoalexin biosynthesis in elicitor-treated Pyrus pyrifolia cell cultures. J. Plant Physiol. 2017, 215, 154-162. [CrossRef]

138. Kim, N.H.; Hwang, B.K. Pepper aldehyde dehydrogenase CaALDH1 interacts with Xanthomonas effector AvrBsT and promotes effector-triggered cell death and defence responses. J. Exp. Bot. 2015, 66, 3367-3380. [CrossRef]

139. Abdul, W.; Aliyu, S.R.; Lin, L.; Sekete, M.; Chen, X.; Otieno, F.J.; Yang, T.; Lin, Y.; Norvienyeku, J.; Wang, Z. Family-Four Aldehyde Dehydrogenases Play an Indispensable Role in the Pathogenesis of Magnaporthe oryzae. Front. Plant Sci. 2018, 9, 980. [CrossRef]

140. Norvienyeku, J.; Zhong, Z.; Lin, L.; Dang, X.; Chen, M.; Lin, X.; Zhang, H.; Anjago, W.M.; Lin, L.; Abdul, W.; et al. Methylmalonatesemialdehyde dehydrogenase mediated metabolite homeostasis essentially regulate conidiation, polarized germination and pathogenesis inMagnaporthe oryzae. Environ. Microbiol. 2017, 19, 4256-4277. [CrossRef]

141. McClerklin, S.A.; Lee, S.G.; Harper, C.P.; Nwumeh, R.; Jez, J.M.; Kunkel, B.N. Indole-3-acetaldehyde dehydrogenase-dependent auxin synthesis contributes to virulence of Pseu-domonas syringae strain DC3000. PLoS Pathog. 2018, 14, e1006811. [CrossRef]

142. Lee, S.G.; Harline, K.; Abar, O.; Akadri, S.O.; Bastian, A.G.; Chen, H.-Y.S.; Duan, M.; Focht, C.M.; Groziak, A.R.; Kao, J.; et al. The plant pathogen enzyme AldC is a long-chain aliphatic aldehyde dehydrogenase. J. Biol. Chem. 2020, $295,13914-13926$. [CrossRef] [PubMed]

143. Carnicero, D.; Fernández-Valverde, M.; Cañedo, L.M.; Schleissner, C.; Luengo, J.M. Octanoic acid uptake in Pseudomonas putida U. FEMS Microbiol. Lett. 2006, 149, 51-58. [CrossRef]

144. Oso, S.; Walters, M.; Schlechter, R.O.; Remus-Emsermann, M.N.P. Utilisation of hydrocarbons and production of sur-factants by bacteria isolated from plant leaf surfaces. FEMS Microbiol. Lett. 2019, 366. [CrossRef] [PubMed] 
145. Dangol, S.; Chen, Y.; Hwang, B.K.; Jwa, N. Iron- and Reactive Oxygen Species-Dependent Ferroptotic Cell Death in RiceMagnaporthe oryzae Interactions. Plant Cell 2019, 31, 189-209. [CrossRef]

146. Kazan, K.; Kalaipandian, S. Ferroptosis: Yet Another Way to Die. Trends Plant Sci. 2019, 24, 479-481. [CrossRef] [PubMed]

147. Distéfano, A.M.; López, G.A.; Setzes, N.; Marchetti, F.; Cainzos, M.; Cascallares, M.; Zabaleta, E.; Pagnussat, G.C. Ferroptosis in plants: Triggers, proposed mechanisms, and the role of iron in modulating cell death. J. Exp. Bot. 2020. [CrossRef]

148. Caseys, C. Ferroptosis: A Companion of ROS in Fighting Magnaporthe in Rice. Plant Cell 2019, 31, 13-14. [CrossRef]

149. Wei, Y.; Lin, M.; Oliver, D.J.; Schnable, P.S. The roles of aldehyde dehydrogenases (ALDHs) in the PDH bypass of Ara-bidopsis. BMC Biochem. 2009, 10, 7. [CrossRef]

150. Kim, J.M.; To, T.K.; Matsui, A.; Tanoi, K.; Kobayashi, N.I.; Matsuda, F.; Habu, Y.; Ogawa, D.; Sakamoto, T.; Matsunaga, S.; et al. Acetate-mediated novel survival strategy against drought in plants. Nat. Plants 2017, 3, 17097. [CrossRef]

151. Sutendra, G.; Kinnaird, A.; Dromparis, P.; Paulin, R.; Stenson, T.H.; Haromy, A.; Hashimoto, K.; Zhang, N.; Flaim, E.; Michelakis, E.D. A Nuclear Pyruvate Dehydrogenase Complex Is Important for the Generation of Acetyl-CoA and Histone Acetylation. Cell 2014, 158, 84-97. [CrossRef]

152. Chen, C.; Li, C.; Wang, Y.; Renaud, J.; Tian, G.; Kambhampati, S.; Saatian, B.; Nguyen, V.; Hannoufa, A.; Marsolais, F.; et al. Cytosolic acetyl-CoA promotes histone acetylation predominantly at H3K27 in Arabidopsis. Nat. Plants 2017, 3, 814-824. [CrossRef] [PubMed]

153. Andrés, F.; Coupland, G. The genetic basis of flowering responses to seasonal cues. Nat. Rev. Genet. 2012, 13, 627-639. [CrossRef] [PubMed]

154. Song, J.; Irwin, J.; Dean, C. Remembering the Prolonged Cold of Winter. Curr. Biol. 2013, 23, R807-R811. [CrossRef] [PubMed]

155. Yu, C.W.; Liu, X.; Luo, M.; Chen, C.; Lin, X.; Tian, G.; Lu, Q.; Cui, Y.; Wu, K. HISTONE DEACETYLASE6 Interacts with FLOWERING LOCUS D and Regulates Flowering in Arabidopsis. Plant Physiol. 2011, 156, 173-184. [CrossRef]

156. Xu, D.; Liu, Q.; Chen, G.; Yan, Z.; Hu, H. Aldehyde dehydrogenase ALDH3F1 involvement in flowering time regulation through histone acetylation modulation on FLOWERING LOCUS C. J. Integr. Plant Biol. 2020, 62, 1080-1092. [CrossRef]

157. Tagnon, M.D.; Simeon, K.O. Aldehyde dehydrogenases may modulate signaling by lipid peroxidation-derived bioactive aldehydes. Plant Signal. Behav. 2017, 12, e1387707. [CrossRef]

158. Morales, M.; Munné-Bosch, S. Malondialdehyde: Facts and Artifacts. Plant Physiol. 2019, 180, 1246-1250. [CrossRef]

159. Chakravorty, D.; Gookin, T.E.; Milner, M.J.; Yu, Y.; Assmann, S.M. Extra-Large G Proteins Expand the Repertoire of Subunits in Arabidopsis Heterotrimeric G Protein Signaling. Plant Physiol. 2015, 169, 512-529. [CrossRef]

160. Pandey, S. Heterotrimeric G-Protein Signaling in Plants: Conserved and Novel Mechanisms. Annu. Rev. Plant Biol. 2019, 70, 213-238. [CrossRef]

161. Liang, Y.; Gao, Y.; Jones, A.M. Extra Large G-Protein Interactome Reveals Multiple Stress Response Function and Part-nerDependent XLG Subcellular Localization. Front. Plant Sci. 2017, 8, 1015. [CrossRef]

162. Fedorova, M. Diversity of Protein Carbonylation Pathways; John Wiley \& Sons, Inc.: Hoboken, NJ, USA, 2017 ; pp. 48-82.

163. Matamoros, M.A.; Kim, A.; Peñuelas, M.; Ihling, C.; Griesser, E.; Hoffmann, R.; Fedorova, M.; Frolov, A.; Becana, M. Protein Carbonylation and Glycation in Legume Nodules. Plant Physiol. 2018, 177, 1510-1528. [CrossRef] [PubMed]

164. Biswas, M.S.; Fukaki, H.; Mori, I.C.; Nakahara, K.; Mano, J. Reactive oxygen species and reactive carbonyl species con-stitute a feed-forward loop in auxin signaling for lateral root formation. Plant J. 2019, 100, 536-548. [CrossRef] [PubMed]

165. Farmer, E.E.; Mueller, M.J. ROS-mediated lipid peroxidation and RES-activated signaling. Annu. Rev. Plant Biol. 2013, 64, 429-450. [CrossRef] [PubMed] 